\title{
PENGARUH PENERAPAN SISTEM PENGENDALIAN INTERNAL PEMERINTAH TERHADAP PENCEGAHAN KECURANGAN
}

\author{
Yuhanis Ladewi \\ Prodi Akuntansi FEB UMP \\ yuhanisladewi@ymail.com \\ Mizan \\ Prodi Akuntansi FEB UMP \\ m124n24@gmail.com
}

\author{
Nunung Nurhayati \\ Universitas Islam Bandung \\ nunung.nurhayati@gmail.com \\ Riska Janatul \\ Prodi Akuntansi FEB UMP \\ hayatiriska45@gmail.com
}

\begin{abstract}
Abstrak
The purpose of this study was to determine the effect of the implementaion of the government internal control system on prevention of fraud in Regional Device Organization Palembang. The variabels in this study used the implementation of the government internal control system. and prevention of fraud. The data used primary data in the from of questionnaires. The analitycal method and analysis techniquesin this study used a quantitative analysis method and descriptive and associative analysis techniques with the help of the Statistical Program Special Science (SPSS). The results of this study indicated that government internal control had effect on the prevention of fraud.
\end{abstract}

Keywords: Government Internal Control, Prevention of Fraud, and Regional Device Organization

Abstrak

Penelitian ini bertujuan untuk mengatahui pengaruh penerapan sistem pengendalian internal pemerintah terhadap pencegahan kecurangan pada Oraganisasi Perangkat Daerah Kota Palembang. Variabel yang digunakan dalam penelitian ini yaitu penerapan sistem pengendalian internal pemerintah sebagai variabael $\mathrm{X}$ dan variabel pencegahan kecurangan sebagai variabel Y. Data yang digunakan adalah data primer dan teknik pengumpualan data menggunakan kuesioner. Metode analisis dan teknik analisis data yang digunakan dalam penelitian ini adalah metode analisis kuantitatif dan teknik analisis deskriptif dan assosiatif dengan bantuan Program Statistical Program Special Science (SPSS). Dari hasil analisis tersebut menunjukan bahwa penerapan sistem pengendalian internal pemerintah berpengaruh terhadap pencegahan kecurangan.

Kata Kunci: Pengendalian Internal Pemerintah, Pencegahan Kecurangan, Organisasi Perangkat Daerah 



\section{PENDAHULUAN}

Pada dasaarnya setiap perusahaan tidak luput dari adanya dukungan sistem informasi akuntansi guna mendukung kelancaran dalam pengoprasian perusahaan. Selain itu sistem juga digunakan untuk mencegah adanya kecurangan. Dalam hal ini setiap perusahaan harus menerpakan sistem pengendalian internal untuk mencegah terjadinya kecurangan. Sistem pengendalian intern adalah suatu sistem yang dibuat untuk memberi jaminan keamanan bagi unsur-unsur yang ada dalam perusahaan (Wiratna, 2015: 69). Ketentuan mengenai penerapan SPIP di lingkungan pemerintah daerah diatur lebih lanjut dengan peraturan gubernur atau peraturan bupati atau walikota. Hal tersebut diperkuat dengan keluarnya Permendagri Nomor 40 Tahun 2010 tentang Penyelenggaraan Sistem Pengendalian Intern Pemerintah (SPIP) di lingkungan pemerintah daerah (Dadang dan Dailibas, 2017: 3). Sistem pengendalian intern pemerintah adalah sistem pengendalian intern yang diselenggarakan secara menyeluruh dilingkungan pemerintah pusat dan daerah. Sistem pengendalian intern pemerintah merupakan suatu proses yang berjalan terus untuk semakin menyempurnakan pencapaian tujuan organisasi. Kegiatan harus fleksibel dan dapat dirubah sesuai dengan kebutuhan, pelaporan keuangan harus semakin andal yang ditunjang dengan SDM yang semakin profesional dan peralatan yang semakin memadai, dan aset semakin aman baik secara administrasi maupun secara fisik (Dadang dan Dailibas, 2017: 4). Pengendalian ini penting karena perusahaan suka atau tidak suka menghadapi banyak ancaman yang bisa mengganggu tercapainya tujuan sistem informasi akuntansi perusahaan (Anastasia dan Lilis, 2011: 82).

Seperti halnya yang dikemukan oleh Tjahjo Kumolo, menyatakan bahwa banyak korupsi yang terjadi karena masih lemahnya sistem tata kelola pemerintah dan faktor kelemahan sistem pengendalian internal. Hal serupa juga didukung oleh pernyataan yang dikemukan M Bahdin, menyebut hasil penelusuran BPKP lemahnya pengendalian intern menjadi salah satu penyebab tiimbulnya korupsi dalam pemerintahan, sistem pengendalian intrnal pemerintah bisa mencegah korupsi, dibandingkan tindakan refresif. Serta hasil audit BPK semester II tahun 2017 mengungkapkan 4.430 temuan yang memuat 5.852 permasalahan meliputi, 1.082 (19\%) permasalahan kelemahan sistem pengendalian intern dan untuk Pemerintah daerah, BUMN dan BLUD ditemukan sebanyak 625 permasalahan kelemahan sistem pengendalian intern.

Kecurangan Kecurangan atau fraud menjadi isu yang sangat sering kita dengar setiap hari. Fraud merupakan suatu perbuatan yang bertentangan dengan kebenaran dan dilakukan dengan sengaja untuk memperoleh sesuatu yang bukan merupakan hak pelakunya, sehingga dapat mengakibatkan kerugiaan pada perusahaan. Kecurangan (fraud) yang biasa terjadi dalam bentuk pencurian harta atau aktiva selain dari uang kas, pencurian uang dengan tidak bertanggung jawab sebagai penerima uang dan pencurian uang dengan melakukan pengeluaran yang tidak sah (Hamdani, 2016: 146). Kecurangan adalah setiap upaya penipuan yang disengaja, yang dimaksudkan untuk mengambil harta atau hak orang atau pihak lain. Dalam kaitannya dengan konteks audit atas laporan keuangan, kecurangan didefinisikan sebagai salah saji laporan keuangan yang disengaja (In the context of auditing financial statements, fraud is defined as an intentional misstatement of financial statements) (Arens, 2012: 336).

Seperti halnya yang dikutip dari kompas.com pada tahun 2017 Saiman, Ketua majelis Hukum mengungkapkan mantan kepala badan pengelolan keuangan aset daerah (BPKAD) Sumatera Selatan, Laoma PL Tobing divonis 5 tahun penjara oleh Majelis Hakim Pengadilan Negri Kelas 1A Khusus Palembang. Ia terbukti melakukan tindak pidana korupsi Pasal 2 Undang-undang Nomor 20 Tahun 2001 tentang Tipikor. Kasus kecurangan yang lainnya terjadi pada tahun 2011 Mantan Kepala Dinas Pekerjaan Umum Bina Marga Provinsi Sumatera Selatan menjadi tersangka kasus korupsi dalam pembangunan Wisma Atlet SEA Games 2011 dan Gedung Serbaguna di Sumatera Selatan. Serta yang diterbitkan oleh trasnsformasinews.com pada tahun 2018 Kepala Dinas PU Cipta Karya Basyarudin dan Pejabat Pembuat Komitmen (PPK) atas dugaan korupsi dan Tindak Pidana Pencucian Uang (TPPU) yang merugikan negara sebesar Rp.151 Miliar. Kegiatan pembangunan jalan lingkungan pada Dinas PU Cipta Karya tahun anggaran 2016 yang merugikan negara diantaranya pembangunan infrastruktur pedesaan Kabupaten Banyuasin, Empat Lawang, Muara Enim, Muratara, Muba, Ogan Ilir, OKI, OKU, OKUS, OKUT, Pali, Lubuklinggau dan Pagaralam. 


\section{KAJIAN PUSTAKA}

\section{Sistem Pengendalian Intenal Pemerintah}

Menurut Peratutan Pemerintah No. 60 Tahun 2008 tentang Sitem Pengendalian Internal Pemerintah menyatkan bahwan sistem pengendalian intern pemerintah adalah sistem pengendalian intern yang diselenggarakan secara menyeluruh dilingkungan pemerintah pusat dan daerah. Sistem pengendalian intern pemerintah merupakan suatu proses yang berjalan terus untuk semakin menyempurnakan pencapaian tujuan organisasi. Kegiatan harus fleksibel dan dapat dirubah sesuai dengan kebutuhan, pelaporan keuangan harus semakin andal yang ditunjang dengan SDM yang semakin profesional dan peralatan yang semakin memadai, dan aset semakin aman baik secara administrasi maupun secara fisik (Dadang dan Dailibas, 2017: 4). Tujuan sistem pengendalian internal yaitu: Untuk menjaga kekayaan organisasi, Untuk menjaga keakuratan laporan keuangan perusahaan, Untuk menjaga kelancaran operasi perusahaan, Untuk menjaga kedisiplinan dipatuhinya kebijakan manajemen, Agar semua lapisan yang ada di perusahaan tunduk pada hukum dan aturan yang sudah ditetapkan di perusahaan (Wiratna, 2015: 69, Mulyadi, 2016:129, Yuhanis, 2012:10). Serta komponen pengendalian internal yaitu: Lingkungan Pengendalian, Penilaian Resiko, Informasi dan Komunikasi, Aktivitas Pengendalian serta Pemantauan (Dadang dan Dailibas 2017: 6, Mulyadi, 2014: 180, dan Wiratna, 2015: 71).

\section{Pencegahan Kecurangan}

Fraud atau kecurangan merupakan suatu tindakan yang dilakukan dengan sengaja oleh pelakunya dan dilakukan dengan melanggar ketentuan yang berlaku untuk mengambil keuntungan demi dirinya sendiri (Hamdani, 2016, Arens, 2012, Mark F dkk, 2014, Irham, 2014, Islahuzzama, 2012, Singleton, 2010). Pencegahan kecurangan dapat dilakukan dengan Memiliki pengendalian internal yang baik, Mengurangi kerjasama antara pegawai dan pihak lain (mencegah terjadinya kolusi), Auditing kecurangan secara proaktif (Proactive fraud auditing), Melakuan seleksi pegawai secara ketat, Membuat ekspetasi hukuman, Sistem pelaporan atau pengaduan dugaan fraud (tips hotline atau whistloblower system) (Mark dkk, 2014: 433, Diaz, 2013: 184, Irham, 2013: 198).

\section{KERANGKA PEMIKIRAN}

\section{Pengaruh penerapan sistem pengendalian internal pemerintah terhadap pencegahan kecuranga}

Sistem pengendalian internal yang lemah dalam sistem birokrasi pemerintahan, dapat menjadi peluang bagi pejabat maupun staf pada instansi pemerintah, hal itu karena tindakan yang dilakukan tidak terdeteksi oleh siapapun. Sebaliknya, jika semakin baik sistem pengendalian internal dalam sistem birokrasi pemerintah, maka tindakan fraud akan sulit dilakukan, karena setiap kegiatan yang dilakukan telah dibatasi dan diawasi oleh tata kelola sistem pengendalian internal. Jadi, semakin efektif tingkat pengendalian internal dalam suatu sistem birokrasi. pemerintah, maka akan semakin kecil pula kesempatan bagi pegawai untuk melakukan fraud. Berdasarkan uraian diatas maka dapat disusun hipotesis sistem pengendalian internal berpengaruh secara signifikan terhadap fraud (kecurangan).

Hal ini sejalan dengan teori yang menyatakan bahwa upaya pencegahan atau Fraud dimulai dari pengendalian intern. Disamping pengendalian intern dua konsep penting lainnya yakni menanamkan kesadaran tentang adanya Fraud (fraud awareness) dan upaya menilai resiko terjadinya Fraud (fraud risk assessment) (Theodorus, 2010:272). Selain itu hal ini juga sejalan dengan hasil penelitian yang dilakukan oleh Muamar, dkk (2017) yang menyatakan bahwa semakin efektif pengendalian internal suatu instansi maka, kecurangan akuntansi yang terjadi akan berkurang. Hasil penelitian ini juga sejalan dengan penelitian yang dilakukan oleh Muqti, dkk (2016) yang menyatakan bahwa semakin diterapkannya pengendalian internal dengan baik di SKPD maka tindakan kecurangan dapat berkurang.

Berdasarkan teori dan kerangka pemikiran yang telah diuraikan sebelumnya maka dapat dirumuskan hipotesis yaitu, penerpan sistem pengendalian internall pemerintah berpengaruh terhadap pencegahan kecurangan. 


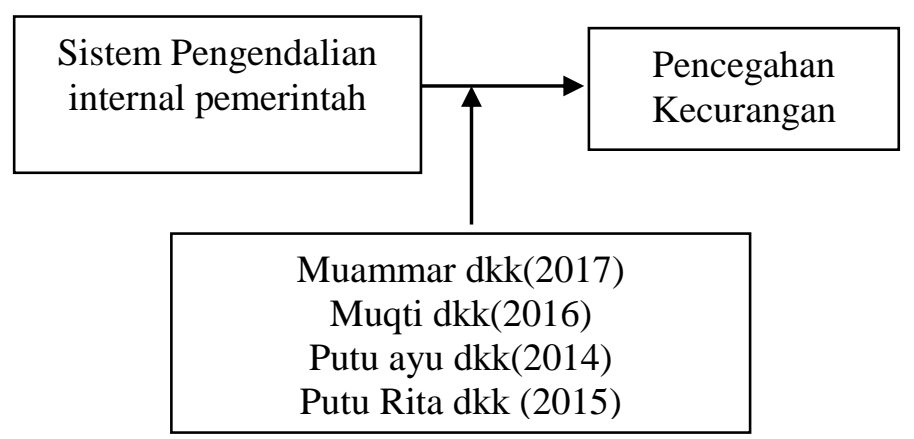

Gambar 1 Kerangka Pemikiran

\section{METODE PENELITIAN}

Jenis penelitian yang digunakan dalam penelitian ini yaitu penelitian assosiatif dan deskriftif (Wiratna, 2014; 11), lokasi penelitian ini dilakukan pada Organisasi Perangkat Daerah Kota Palembang. Variabel yang digunakan dalam penelitian ini yaitu penerapan sistem pengendalian internal pemerintah dan pencegahan kecurangan. Populasi yang digunakan dalam penelitian ini yaitu sebanyak 28 OPD Kota Palembang. Adapun sampel yang digunakan dalam penelitian ini yaitu sebanyak 24 OPD diantaranya para pegawai yang melaksanakan fungsi akuntansi/ tata usaha keuangan OPD, Kepala staf subbagian akuntansi/ penatausahaan keuangan, serta pada bagian sistem pengendalian intern pemerintah, penarikan sampel dilakukan secara purposive sampling (Sekaran, 2013; 67). Data yang digunakan dalam penelitian ini adalah data primer dan data sekunder, metode pengumpulan data yang digunakan penulis dalam penelitian ini adalah teknik interview dan kuesioner (Wiratna, 2014; 74-75). Metode pengujian data dalam penelitian ini yaitu uji validitas dan uji reliabilitas (Albert, 2014; 89). Analisis data yang digunakan dalam penelitian ini yaitu analisis kuantitatif dan kualitatif, analisis kuantitatif dilakukan dengan menggunakan pengujian statistik dari hasil kuesioner, kemudian hasil pengujian tersebut akan dijelaskan dalam bentuk kalimat dan dibantu dengan program for special science (SPSS) dan software program miscosoft successifn interval (MSI) yang berupa penilaian dari hasil pengisian kuesioner (Albert, 2014; 89)

\section{HASIL PENELITIAN DAN PEMBAHASAN}

\section{Uji Validitas}

Hasil uji validitas dengan menggunakan uji korelasi product moment syarat minimum suatu item dianggap valid apabila nilai total person correlation atau nilai $r_{\text {hitung }} \geq$ dari 0,361 maka dinyatakan valid dan sebaliknya apabila nilai $r_{\text {hitung }} \leq$ dari 0,361 maka dinyatakan tidak valid (Sugiyono, 2015; 317), dengan bantuan program SPSS dapat dilihat bahwa untuk item pertanyaanvaliabel penerapan sistem pengendalian internal pemerintah memperoleh nilai $r$ hitung berkisar antara 0,469-0,771 yang dapat disimpulkan bahwa untuk item pertanyan variabel sistem pengendalian internal pemerintah seluruhnya dinyatakan valid.

Untuk item pertanyaan variabel pencegahan kecurangan memperoleh nilai $r$ hitung berkisar antara 0,498 0,708 yang dapat disimpulkan bahwa untuk item pertanyaan variabel pencegahan kecurangan seluruhnya dinyatakan valid dan dapat disertakan dalam analisis selaanjutnya.

\section{Uji Reliabilitas}

Secara umum untuk hasil uji reliabilitas dengan bantuan SPSS suatu instrumen atau pernyataan dikatakan reliabel apabila nilai koefesien Cronbach's Alpha $\geq 0,6$. Berdasarkan hasil uji reliabilitas dapat diketahui bahwa nilai cronbach's alpha untuk masing-masing variabel yaitu variabel sistem pengendalian internal pemerintah (X) diperoleh 0,774 >0,6 yang berarti variabel tersebut dapat dinyataka reliabel, dan untuk variabel pencegahan kecurangan (Y) diperoleh nilai cronbach's alpha sebesar 0,797 >0,6 dalam artian variabel pencegahan kecurangan juga dinyatakan reliabel. Dengan demikian berdasarkan hasil uji reliabilitas terhadap masing-masing variabel penelitian maka dapat disertakan dalam analisis selanjutnya. 


\section{Analisis Statistik Deskriptif}

Hasil analisis statistik deskriptif menggambarkan atau mendeskripsikan suatu data yang dilihat dari frekuensi, nilai, mean, dan standar deviasi dari masing-masing variabel penelitian.

Tabel 1. Frekuensi Variabel Sistem Pengendalian Internal Pemerintah (X) dan Variabel Pencegahan Kecurangan (Y)

Tabel 1

Descriptive Statistics

\begin{tabular}{|c|r|r|r|r|r|}
\hline & $\mathrm{N}$ & Min & Max & Mean & $\begin{array}{c}\text { Std. } \\
\text { Deviation }\end{array}$ \\
\hline $\begin{array}{c}\mathrm{X} \\
\text { Valid N } \\
\text { (listwise) }\end{array}$ & 72 & 34.00 & 50.00 & 41.43 & 2.95 \\
\hline $\begin{array}{c}\mathrm{Y} \\
\text { Valid N } \\
\text { (listwise) }\end{array}$ & 72 & 29.00 & 50.00 & 41.13 & 3.40 \\
\hline
\end{tabular}

Sumber: Hasil Pengelolaan Data, 2018

Tabel 1 menjelaskan bahwa jumlah $\mathrm{N}$ dari penelitian ini adalah 72, nilai 72 diperoleh dari jumlah responden yang dijadikan sampel penelitian. Pada variabel sistem pengendalian internal pemerintah nilai terkecil adalah 34 dan nilai terbesar adalah 50, nilai rata-rata sebesar 41,43 dan nilai deviasi sebesar 2,95. Nilai rata-rata cendrung mendekati nilai terkecil hal ini menunjukan bahwa mayoritas OPD yang dijadikan sampel memiliki sistem pengendalian internal pemerintah yang relatif rendah. Untuk variabel pencegahan kecurangan nilai terkecil adalaah 29, nilai terbesar adalah 50, nilai rata-rata sebesar 41,13 dan nilai deviasi sebesar 3,4. Nilai rata-rata mendekati nilai terbesar sehingga menunjukan bahwa variabel pencegahan kecurangan relatif tinggi.

\section{Analisis Statistik Deskriptif Per Indikator}

Tabel 2. Statistik Deskriptif Per Indikator Variabel Siste

Pengendalian internal Pemerintah (X)

Descriptive Statistics

\begin{tabular}{|l|r|r|r|r|r|r|r|}
\hline & N & Min & Max & Sum & Mean & Std. Deviation & Variance \\
\hline P1 & 72 & 2.00 & 5.00 & 315.00 & 4.3750 & .59191 & .350 \\
P2 & 72 & 3.00 & 5.00 & 299.00 & 4.1528 & .46451 & .216 \\
\hline P4 & 72 & 3.00 & 5.00 & 297.00 & 4.1250 & .50176 & .252 \\
\hline P5 & N & Min & Max & Sum & Mean & Std. Deviation & Variance \\
\hline P6 & 71 & 3.00 & 5.00 & 304.00 & 4.2817 & .56526 & .320 \\
P7 & 72 & 3.00 & 5.00 & 292.00 & 4.0556 & .55383 & .307 \\
Pa & 72 & 3.00 & 5.00 & 302.00 & 4.1944 & .52107 & .272 \\
\hline & 72 & 3.00 & 5.00 & 299.00 & 4.1528 & .45943 & .211 \\
\hline
\end{tabular}

Sumber: Hasil Pengelolan Data, 2018

ISSN : 1693-0164 | e-ISSN : 2581-074X 
Tabel 2 menjelaskan bahwa jumlah $\mathrm{n}$ dari penelitian ini adalah 72, nilai 72 diperoleh dari jumlah responden dan dapat dillihat keseluruhan pernyataan nilai terkecil yaitu 3, nilai terbesar yaitu 5 dengan nilai rata-rata 4,28 serta nilai standar deviasi 0,337 artinya dapat disimpulkan bahwa rata-rata responden menyatakan setuju bahwa sistem pengendalian internal pemerintah sangat diperluka di suatu instansi guna mencegah kecurangan.

Tabel 3. Statistik Deskriptif Per Indikator Variabel Pencegahan Kecurangan (Y) Descriptive Statistics

\begin{tabular}{|l|r|r|r|r|r|r|r|}
\hline & $\mathrm{N}$ & \multicolumn{1}{c|}{ Min } & Max & Sum & Mean & Std. Dev & \multicolumn{1}{c|}{ Variance } \\
\hline P1 & 72 & 3.00 & 5.00 & 303.00 & 4.2083 & .47285 & .224 \\
P2 & 72 & 3.00 & 5.00 & 300.00 & 4.1667 & .47471 & .225 \\
P3 & 72 & 3.00 & 5.00 & 295.00 & 4.0972 & .53497 & .286 \\
P4 & 72 & 3.00 & 5.00 & 297.00 & 4.1250 & .52908 & .280 \\
P5 & 72 & 2.00 & 5.00 & 295.00 & 4.0972 & .69525 & .483 \\
P6 & 72 & 3.00 & 5.00 & 292.00 & 4.0556 & .44051 & .194 \\
P7 & 72 & 2.00 & 5.00 & 295.00 & 4.0972 & .63156 & .399 \\
P8 & 72 & 2.00 & 5.00 & 300.00 & 4.1667 & .67135 & .451 \\
P9 & 72 & 3.00 & 5.00 & 295.00 & 4.0972 & .53497 & .286 \\
VAR00010 & 72 & 3.00 & 5.00 & 290.00 & 4.0278 & .67076 & .450 \\
Valid N (listwise) & 72 & & & & & \\
\hline
\end{tabular}

Sumber : Hasil Pengelolaan Data, 2018

Tabel 3 menjelaskan bahwa jumlah nilai n dari penelitian adalah 72, nilai 72 diperoleh dari jumlah responden dan dapat dilihat keseluruhan pernyataan nilai terkecil yaitu 3 dan nilai terbesar yaitu 5 dan nilai rata-rata 4,20 serta nilai standar deviasi 0,69 yang artinya dapat disimpulkan bahwa rata-rata responden menjawab setuju bahwa pencegahan dapat dilakukan dengan melakukan sistem pengendalian internal yang baik.

\section{Analisis Statistik Assosiatif}

\section{Uji Regresi Linear Sederhana}

Tabel 4. Hasil Uji Linear Sederhana

Coefficients $^{\mathrm{a}}$

\begin{tabular}{|c|c|c|c|c|c|c|c|}
\hline \multirow[b]{2}{*}{ Model } & \multicolumn{2}{|c|}{$\begin{array}{l}\text { Unstandardized } \\
\text { Coefficients }\end{array}$} & \multirow{2}{*}{$\begin{array}{c}\begin{array}{c}\text { Standardized } \\
\text { Coefficients }\end{array} \\
\text { Beta }\end{array}$} & \multirow[b]{2}{*}{$\mathrm{t}$} & \multirow[b]{2}{*}{ Sig. } & \multicolumn{2}{|c|}{$\begin{array}{l}\text { Collinearity } \\
\text { Statistics }\end{array}$} \\
\hline & B & Std. Error & & & & $\begin{array}{c}\text { Toleranc } \\
\mathrm{e}\end{array}$ & VIF \\
\hline $\begin{array}{l}\text { 1(Consta } \\
\text { nt) }\end{array}$ & 7.763 & 2.662 & & 2.917 & .005 & & \\
\hline$X$ & .759 & .088 & .716 & 8.593 & .000 & 1.000 & 1.000 \\
\hline
\end{tabular}

a. Dependent Variable: Y

Sumber : Hasil Pengelolaan Data, 2018

Berdasarkan hasil uji regresi linear sederhana yang telah dilakukan dengan bantuan program SPSS dalam penelitian ini memperoleh persamaan regresi linear sederhana sebagai berikut: 
$\mathrm{Y}=7,763+0,759 \mathrm{X}$

Keterangan:

$\mathrm{Y}=$ nilai prediksi dari variabel $\mathrm{Y}$ berdasarkan variabel $\mathrm{X} \backslash$

$\mathrm{a}=$ titik potong $\mathrm{Y}$, merupakan nilai bagi $\mathrm{Y}$ ketika $\mathrm{X}=0$

$\mathrm{X}=$ Nilai variabel $\mathrm{X}$ yang dipilih

Persamaan:

a. Konstanta memiliki nilai 7,763, maka pencegahan kecurangan (Y) nialinya 7,763

b. Koefisien regresi sistem pengendalian internal pemerintah (X) sebesar 0,759 menyatakan bahwa setiap peningkatan sistem pengendalian internal pemerintah sebesar satuan maka akan menambah peningkatan pencegahan kecurangan sebesar 0,759

\section{Uji Determinasi}

Tabel 5. Hasil Uji Koefesien Determinasi

\begin{tabular}{|c|c|c|c|c|c|}
\hline \multicolumn{6}{|c|}{ Model Summary $^{b}$} \\
\hline Model & $\mathrm{R}$ & R Square & $\begin{array}{l}\text { Adjusted R } \\
\text { Square }\end{array}$ & $\begin{array}{c}\text { Std. Error of the } \\
\text { Estimate }\end{array}$ & Durbin-Watson \\
\hline 1 & $.716^{\mathrm{a}}$ & .513 & .506 & 3.54803 & 2.114 \\
\hline \multicolumn{6}{|c|}{ a. Predictors: (Constant), X } \\
\hline \multicolumn{3}{|c|}{ b. Dependent Variable: Y } & & & \\
\hline
\end{tabular}

Sumber : Hasil Pengelolaan Data, 2018

Tabel 5 menunjukan bahwa hasil uji determinasi menunjukan bahwa nilai R Square sebesar 0,513 hasil ini berarti menunjukan bahwa terdapat pengaruh variabel sistem pengendalian internal pemerintah (X) terhadap pencegahan kecurangan (Y) sebesar 0,513 atau 51,3\%. Sementara 48,7\% dipengaruhi oleh variabel lain diluar model yang tidak diteliti.

\section{Uji Hipotesis}

Uji Parsial (Uji t)

Tabel 6. Hasil uji Hipotesis Secara Parsial Atau Individual t

\section{Coefficients $^{\mathrm{a}}$}

\begin{tabular}{|c|c|c|c|c|c|c|c|}
\hline \multirow[b]{2}{*}{ Model } & \multicolumn{2}{|c|}{$\begin{array}{l}\text { Unstandardized } \\
\text { Coefficients }\end{array}$} & \multirow{2}{*}{\begin{tabular}{|c}
$\begin{array}{c}\text { Standardiz } \\
\text { ed } \\
\text { Coefficient } \\
\text { s }\end{array}$ \\
Beta
\end{tabular}} & \multirow[b]{2}{*}{$\mathrm{t}$} & \multirow[b]{2}{*}{ Sig. } & \multicolumn{2}{|c|}{$\begin{array}{l}\text { Collinearity } \\
\text { Statistics }\end{array}$} \\
\hline & B & $\begin{array}{l}\text { Std. } \\
\text { Error }\end{array}$ & & & & $\begin{array}{c}\text { Toleranc } \\
\mathrm{e}\end{array}$ & VIF \\
\hline 1(Constant) & 7.763 & 2.662 & & 2.917 & .005 & & \\
\hline $\mathrm{X}$ & .759 & .088 & .716 & 8.593 & .000 & 1.000 & 1.000 \\
\hline
\end{tabular}

a. Dependent Variable: Y

Sumber: Hasil Pegolaan Data, 2018 
Pengaruh Penerapan Sistem Pengendalian Internal Pemerinta (X) Terhadap Pencegahan Kecurangan (Y)

Hasil uji hipotesis menunjukan bahwa diketahui nilai $t_{\text {hitung }}$ untuk variabel sistem pengendalian internal pemerintah $(\mathrm{X})$ sebesar 8,593, sedangkan nilai $\mathrm{t}_{\text {tabel }}$ dengan $\propto 0,005$ atau 5\% serta serta $\mathrm{df}=\mathrm{n}-\mathrm{k}-1(72-1-1)=70$ adalah sebesar 1,994 sehingga $t_{\text {hitung }} 8,593>\mathrm{t}_{\text {tabel }}$ 1,994 maka dapat disimpulkan bahwa sistem pengendalian internal pemerintah berpengaruh positif dan signifikan terhadap pencegahan kecurangan artinya hipotesis diterima.

\section{PEMBAHASAN}

Berdasarkan uji analisis dan uji hipotesis yang telah penulis lakukan penelitian ini menunjukan bahwa penerapan sistem pengendalian internal pemerintah berpengaruh terhadap pencegahan kecurangan. Berdasarkan hasil koefesien korelasi dan nilai koefesien determinasi serta uji hipotesis yang dilakukan menunjukan bahwa hipotesis yang diajukan tentang penerapan sistem pengendalian internal pemerintah berpengaruh terhadap pencegahan kecurangan namun masih banyak variabel lain yang mempengaruhi.

Lingkungan pengendalian sangat dibutuhkan dalam suatu instansi karena merupakan landasan untuk semua unsur pengendalian intern,yang membentuk disiplin dan struktur. Unsur lingkungan pengendalian salah satunya yaitu membangun komitmen terhadap kompetensi dengan cara dengan cara melakukan seleksi pegawai yang ketat selalu didasarkan pada standar kompetensi dan values sebagaimana telah dibangun dan ditetapkan oleh pimpinan instansi pemerintah. Dalam tahapan ini harus dipilih kandidat dengan latar belakang pendidikan, model atau jenis seleksi dan materi seleksi yang tepat, sehinggga diperoleh pegawai tepat juga sesuai dengan standar kompetensi dan values yang ditetapkan oleh suatu instansi. Sehingga lingkungan pengendalian dapat mencegah terjadinya kecurangan apabila melakukan seleksi pegawai yang ketat. Hal ini dapat dilihat dari jawaban para responden dari bebera Organisasi Perangkat Daerah dimana, di beberapa OPD Kota Palembang masih ada OPD yang tidak melakukan seleksi pegawai dengan ketat.

Peranan aparat pengawas intern pemerintah (APIP) melakukan pengawasan denga cara melakukan audit, reviu, evaluasi, pemantauan dan kegiaatan pengawasan lainya. Dengan memperhatikan beberapa peratutan yang terkait dengan tugas dan peran APIP. Walaupun peran APIP tidak dapat menjamin bahwa kecurangan tidak akan terjadi, namun ia harus menggunakan kemahiran jabatanya dengan seksama sehingga diharapkan mampu mendeteksi terjadinya kecurangan dan dapat mendapatkan saran-saran yang bermafaat kepada manajemen untuk mencegah kecurangan. Resiko yang dihadapai intasnsi diantaranya resiko adanya kecurangan dari pimpinan instansi ataupun pegawai, tindakan ilegal, ataupun tindak penyimpangan lainnya. Adanya resiko tersebut mengharuskan APIP untuk menyusun tindakan pencegahan kecuranga melaui dengan melakukan audit kecurangan proaktif.

Kegiatan pengendalian diperlukan untuk menerapkan unsur pemisahan tugas, pembagian tugas. Memisahkan fungsi operasi dan penyimpanan dari fungsi akuntansinya, dan satu fungsi, tidak boleh melaksanakan semua tahapan suatu transaksi. Jika semua fungsi disatukan, akan membuka kemungkinan terjadinya kecurangan. Dengan melakukan pemisahan tugas tingkat kecurangan dapat dicegah. Hal menunjukan kegiatan pengendalian dapat mencegah kecurangan apabila instansi melakukan pemisahan tugas.

Pengendalian umum, pengamanan sistem informasi, pengendalian akses, dan pengendalian perangkat lunak. Pengendalian umum, kegiatan pengendalian atas pengelolaan sistem informasi dilakukan untuk memastikan akurasi dan kelengkapan informasi. Kegiatan pengendalian ini meliputi pengendalian umum yang terdiri dari pengamanan sistem informasi, pengendalian atas akses, pengendalian atas pengembangan dan perubahan perangkat lunak aplikasi, dan pemisahan tugas dengan melakukan pengendalian umum dapat mencegah terjadinya kecurangan dengan cara pengimlementasian pengendalian internal melalui pemeriksaan berkala terhadap sistem komputerisasi. Hal ini menunjukan pengendalian umum dapat mencegah kecurangan dengan melakuakn pemeriksaan berkala terhadap sistem komputerisasi dan data.

Pemimpin instansi pemerintah juga harus memastikan bahwa sudah terjalin komunikasi eksternal yang efektif, komunikasi dengan pihak eksternal sangat didorong untuk mengetahui berfungsinya pengendalian intern. Pengaduan, keluhan, dan pernyatan mengenai layanan instansi pemerintah ditindaklanjuti dengan baik karena dapat menunjukan permasalahan dalam pengendalian. Dengan komunikasi yang efektif dengan pihak internal maka pencegahan kecurangan dapat dilakukan dengan membuat sistem pelaporan atau pengaduan dugaan fraud, sehingga pengaduan dari pihak eksternal dapat menunjukan permasalahan yang ada, dengan demikian maka 
komunikasi yang efektif dengan pihak eksternal dapat mencegahkan kecurangan dengan membuat sistem pengaduan atau pelaporan dugaan fraud.

\section{Kesimpulan \\ Kesimpulan}

Berdasarkan hipotesis penelitian bahwa penerapan sistem pengendalian internal pemerintah berpengaruh terhadap pencegahan kecurangan, dalam penelitian ini terbukti secara empiris bahwa penerapan sistem pengendalian internal pemerintah berpengaruh terhadap pencegahan kecurangan dengan penelitian ini dapat membuktikan teori dan penelitian-penelitian sebelumnya.

\section{Daftar Pustaka}

Anastasia dan Lilis. (2011). Sistem Iformasi Akuntansi Yogyakarta C.V Andi Offetss

Albert Kurniawan (2014). Metode Riset Untuk Ekonomi \& Bisnis: Teori, Konsep \& Praktik Penelitian Bisnis (Dilengkapi Perhitungan Pengelolahan Data Dengan IBM SPSS 22.0). Bandung: Alfabeta

Alvin A. Arens, Randal J. Elder dan Mark S. Beasley. (2012). Auditing and Assurance Service. Erlangga

Boyamin. (2018). Kadis PUCK Sumsel Diduga Rugikan Negara 151 Milyard. Diakses 28 April 2018, 13:30 WIB. www.transformasinews.com

BPK RI. (2017). Ikhtisar Hasil Pemeriksaan Semester II 2017. Diakses 2 Mei 2018, 13:00 WIB. www.bpk.goid/ihps

Dadang dan Dailibas. (2017). Sistem Pengendalian Intern Pemerintah. Jakarta: PPM

Diaz Priantara. (2013). FRAUD AUDITING \& INVESTIGATION. Jakarta: Mitra Wacana Media

Hamdani. (2016). Good Corporate Govarnance Tinjauan Etika Dalam Praktik Bisnis. Jakarta: Mitra Wacana Media

Herry. (2014) Pengendaliaan Akuntansi dan Manajemen

Irham Fahmi. (2014). ETIKA BISNIS Teori, Kasus, dan Solusi. Bandung: Alfabeta

Isyahuzzaman. (2012). Istilah-Istilah Akuntansi \& Auditing. Jakarta: Bumi Aksara

Mark F. Zimbelman, Conan C. Albercht, W. Steve Albercht, Chad O. Albercht. (2014). Akuntansi Forensik Forensic Accounting. Jakarta: Salemba Empat

M. Bahdin. (2014). Lemahnya Pengendalian Internal Penyebab Korupsi. Diakses 4 Mei 2018, 15:00 WIB. Beritasatu.com

Moermahadi Soerja Djanegara. (2016). Untuk Ketiga Kalinya, Laporan Keuangan DKI Jakarta Dapat Opini WDP dari BPK. Alsadad Rudi. Diakses 28 April 2018, 12:30 WIB. www.Kompas.com

Mulyadi. (2014). Auditing. Jakarta: Salemba Empat

Mulyadi. (2016). Sistem Akuntansi. Jakarta: Salemba Empat

Muammar Rizky dan Fauziah Aida Fitri. (2017). Pengaruh Keefektifan Pengendalian Internal, Ketaatan Aturan Akuntansi, Penegakan Hukum, Dan Perilaku Tidak Etis Terhadap Kecurangan Akuntansi. Vol. 2, No. 2, (2017) Halaman 10-20. Diakses 19 April 2018. Dari http://jim.unsyiah.ac.id/EKA/article/view/2409

ISSN : 1693-0164 | e-ISSN : 2581-074X 
Muqti Randy Syarif. (2016). Pengaruh Pengendalian Internal, Good Governance, Peranan Auditor Internal, Dan Keadilan Organisasi Terhadap Tingkat Kecurangan (Studi Pada SKPD Kabupaten Rokan Hulu). Vol.3 No.1 (Februari) 2016. Diakses 19 April 2018. Dari https://media.neliti.com/media/publications/186520-IDpengaruh pengendalian-internal-good-gove.pdf

Ni Luh Putu Purnama Sari, Gede Adi Yuniarta, I Made Pradana Adiputra. (2015). Pengaruh Efektifitas Sistem Pengendalian Internal, Ketaatan Aturan Akuntansi, Persepsi Kesesuaian Kompensasi Dan Implementasi Good Governance Terhadap Kecenderungan Fraud (Studi Empiris Pada Skpd Di Kabupaten Tabanan). $\begin{array}{llllllll}\text { Volume 3, No.1 } & \text { Tahun 2015. Diakses } 15 & \text { Maret } & \text { 2018. }\end{array}$ https://ejournal.undiksha.ac.id/index.php/S1ak/article/view/4677

Nurul Wadiasih. (2017). Korupsi Wisma Atlet, Eks Kepala Dinas PU Sumsel Dituntut 5,5 Tahun Penjara. Ambaranie, Nadia Kemala, Movanita. Diakses 25 April 2018, 09:30 WIB. Kompas.com

Priyastama, Romie. (2017). Buku Sakti Kuasai SPSS: Pengolahan Dan Analisis Data. Star Up. Yogyakarta: Anak Hebat Indonesia

Putu Ayu Ratnayani, Edy Sujana, Nyoman Ari Surya Darmawan. (2014). Pengaruh Pengendalian Intern Kas dan Implementasi Good Corporate Governance Terhadap Fraud (Studi Empiris pada SKPD di Kabupaten Buleleng). Vol: 2 No:1 Tahun 2014. Diakses 23 Maret 2018. Dari https://ejournal.undiksha.ac.id/index.php/S1ak/article/viewFile/2293/1985

Putu Rita Saftarini, Gede Adi Yuniarta, Ni Kadek Sinarwati. (2015). Pengaruh Efektivitas Pengendalian Internal, Asimetri Informasi Dan Implementasi Good Governance Terhadap Kecenderungan Kecurangan (Fraud) Akuntansi (Studi Empiris Pada SKPD di Kabupaten Bangli). Volume 3 No. 1 Tahun 2015. Diakses 27 Maret 2018. Dari https://ejournal.undiksha.ac.id/index.php/S1ak/article/view/5245

Saiman. (2017). Korupsi Dana Hibah Kepala BPKAD Sumsel Divonis 5 Tahun Penjara. Diakses 27 Maret 2018 , 13:30 WIB. Kompas.com

Sugiyono. 2016. Metode Penelitian Pendidikan Pendekatan Kuantitatif dan Kualitatifdan R\&D. Bandung: Alfabeta

Theodorus M. Tuanakotta. (2010). Akuntansi Forensik dan Audit Investigatif. Jakarta: Salemba Empat

Theodorus M. Tuanakotta. (2016). Audit Kontemporer. Jakarta: Salemba Empat

Tjahjo Kumolo. (2016). Mendagri Nilai Korupsi di Daerah Bisa Terjadi Karena Kelemahan Sistem. Ihsanuddin. Diakses 3 April 2018, 15:30 WIB. www.Kompas.com

Tommie W. Singelton, Aaron J. Singelton. (2010). Fraud Auditing and Forensic Accounting.

V. Wiratna Sujarweni. (2015). Sistem Informasi Akuntansi. Yogyakarta: Pustaka Baru Press

V. Wiratna Sujarweni. (2014). Metode Penelitian Lengkap, Praktis, dan Mudah Dipahami (Cetakan Pertama). Yogyakarta: Pustakapress

Yuhanis Ladewi. (2012). Sistem Informasi Akuntansi Teori dan Praktek. Palembang: Fakultas Ekonomi Universitas Muhammadiyah Palembang. 